\title{
Productive Performances of Crossbred Dairy Cattle at Holetta Agricultural Research Center
}

\author{
Kefale Getahun $^{1^{*}} \quad$ Million Tadesse $^{1} \quad$ Direba Hundie $^{1} \quad$ Yosef Tadesse $^{2}$ \\ 1. Ethiopian Institute of Agricultural Research, Holetta Agricultural Research Center, \\ P.O. Box 2003 Addis Ababa or 31 Holetta, Ethiopia \\ 2. Haramaya University, School of Animal and Range Science, P.O. Box 138 Dire Dawa, Ethiopia
}

\begin{abstract}
This study was conducted to evaluate the productive performances of crossbred dairy cattle at Holetta research center dairy farm. A total of 6685 performance records were used and analyzed to determine the effect of period of calving, season of calving, parity and genetic group. The parameters used us indicator of productive performances were Lactation milk yield (LMY), daily milk yield (DMY) and lactation length (LL). The GLM procedure of SAS 2004 software was used for analysis. The overall least square means and standard errors for Lactation milk yield (LMY), daily milk yield (DMY) and lactation length (LL) were $\div 2204.05 \pm 21.12 \mathrm{~kg}, 6.88$ $\pm 0.05 \mathrm{~kg}$ and $326.69 \pm 2.03$ days, respectively. Result of fixed effect analysis indicated that calving period, genetic group and parity were significantly $(\mathrm{p}<0.001)$ influenced all productive traits. LMY, DMY and LL were sensitive to seasonal variation. Comparisons among the crosses revealed a clear-cut difference among the genetic groups. Milk production in the first generation crosses increased more compared to second generations. There were marked decline in performance among $50 \% \mathrm{~F}_{1}$ (Borena dam $\mathrm{x}$ Holstein Friesian sire), $\mathrm{F}_{2}\left(\mathrm{~F}_{1}\right.$ dam $\mathrm{x} \mathrm{F}_{1}$ sire) and $F_{3}\left(F_{2}\right.$ dam $\times F_{2}$ sire) from $2203 \mathrm{~kg}$ of milk to 1697 and $1522 \mathrm{~kg}$, respectively. The $75 \%$ first generation was superior LMY compared with other genetic groups and produced about $34.2 \%, 74.3 \%, 94.3 \%$ and $45.9 \%$ more milk than $50 \% \mathrm{~F}_{1}, \mathrm{~F}_{2}, \quad \mathrm{~F}_{3}$ and $75 \%$ second generations, respectively. The higher milk yield of $75 \%$ first generation and $50 \% \mathrm{~F}_{1}$ crosses from other genetic groups could be associated with higher heterosis effect in $\mathrm{F}_{1}$, higher milk gene in $75 \%$ and longer lactation length. Based on the productive performances evaluation, the results of LMY, DMY and LL of higher grades $(>50 \%)$ in the present study revealed that performances were continued to increase with increasing proportion of exotic genes.
\end{abstract}

Keywords: Borena, Ethiopia, Holetta, Holstein Friesian

DOI: $10.7176 /$ FSQM/92-04

Publication date: December $31^{\text {st }} 2019$

\section{INTRODUCTION}

The importance of livestock is growing over the years because of increment of human population, rising incomes and urbanization in developing countries. These factors fuel a massive increase in demand for foods of animal origin. The projected increase in demand of animal products which are expected to drive major changes in the livestock sector during the period to 2020, a process that has been termed "the livestock revolution" (FAO 2010). Dairy products are among some of the most important commodities from the livestock sector and the strongest growth in demand for milk and milk products is anticipated to come from developing countries. World production of milk is forecasted to grow by an annual rate of slightly over one percent and the largest increment is expected in developing countries (Griffin 1999). 2017). However, breed improvement and development programs have been directed mainly on crossbreeding activities through research stations, few government stock multiplication centers and private farms (MOARD, Ministry of Agriculture and Rural Development 2007). This was mainly attributed to the assumption that the genetic gain expected from selection of indigenous cattle is 1-2 percent per year (Braännäng and Person 1990) which is too slow to support the immediate high demand of milk in the country. In this regard, the introductions of exotic breeds have been suggested as one option to improve milk production and fill the gap between milk demand and supply in the country. However, exotic breeds become expensive and risky because they are susceptible to diseases and the cost of milk production is often greater than the gross income that can be obtained (Tesfaye 1990).

Crossbred cows have been reported to be more productive than purebred cows in the tropics (McDowell 1985; Cunningham and Syrstand 1987). Despite the promising productive performance of crossbred dairy cattle, high demand for milk and efforts to multiply in Ethiopia, well-organized and successful crossbreeding programs could not generate significant number of improved crossbred dairy cattle compared to the proportion of indigenous breeds and remains few. It has been one implication that out of 60.39 million head, only $1.54 \%$ are crossbred (CSA 2017) over 80 years of crossbreeding activities in the country. This could be associated with less efficient service delivery and lack of suitable breeding program to generate adaptive and productive generations.

A long-term crossbreeding program initiated in 1974 at Holetta Agricultural Research Center has been produced several generations of crosses between the indigenous Boran and Friesian breed with the aim of combining productivity and adaptability in the crossbreds. This crossbreeding effort resulted in the development 
of various genetic groups $\left(50 \% \mathrm{~F}_{1}, \mathrm{~F}_{2}, \mathrm{~F}_{3}\right.$ and $75 \%$ first and second generations) which intervened for improving the breeding program. The effect of exotic blood level, random change of environments and introducing of management factors could be influence the productive performances of crossbred dairy herd in the research center. Although, some research have been conducted to evaluate the performance of Friesian and Borena crosses at Holetta, regular evaluation of productive performances of the herd is a key indicator of sustainability of a dairy cattle research and the breeding program and this performance evaluation is depends on LMY, DMY and LL parameters of economic important traits. The objective of this study was therefore, to evaluate trend of productive performances of crossbred dairy cows over the years and to estimate the extent of non-genetic and genetic factors affected the long-term crossbred dairy cattle at the research center.

\section{MATERIALS AND METHODS \\ Description of the study area}

This research was conducted at Holetta Agricultural Research Center (HARC). Holetta is located in the central highland of Ethiopia at $35 \mathrm{~km}$ west of Addis Ababa $\left(3^{\circ} 24^{\prime} \mathrm{N}\right.$ to $14^{0} 53^{\prime} \mathrm{N}$ latitude and $33^{0} 00^{\prime} \mathrm{E}$ to $48^{0} 00^{\prime} \mathrm{E}$ longitude) with an altitude of 2400 meter above sea level. The average annual rainfall is $1100 \mathrm{~mm}$ and average temperature is $15^{0} \mathrm{C}$ with minimum of $6{ }^{0} \mathrm{C}$ and maximum of $24{ }^{0} \mathrm{C}$ (Yohannes et al. 2016). The average monthly relative humidity is $60 \%$ (Gebregziabhere et al. 2013).

Data source and data collection

Data for the study was obtained from long-term (1974 - 2017) crossbred research of dairy cattle herd of Ethiopian Borena $\mathrm{x}$ Holstein Friesian crossbred cattle maintained at the research station and therefore, different exotic gene inheritances ranging from $50 \%$ to $75 \%$ of HF (Holstein Friesian) were considered for this study.

\section{Animal management}

The cattle were herded based on breed, pregnancy, lactation stage, sex and age. Uniform feeding and management practices were adopted for all animals within each category. Natural grazing, hay and concentrate supplement constituted the major feed supply. During the day time animals were allowed to graze on pastureland from early morning 8.00 AM to 4.00 PM. Natural pasture hay was provided as additional feed during the evening. Concentrate mixture composed of wheat middling (32\%), wheat bran (32\%), noug (Guizocia abyssinica) cake $(34 \%)$ and salt $(2 \%)$ was supplemented based on their body weight, productivity and physiological categories. Milking cows, heifers and calves were supplemented with concentrate mixture at a rate of 4, 1-1.5 and $0.25-1 \mathrm{~kg}$ per day, respectively depending up on availability of supplemental feed. The cows had free access to clean tap water all the time.

Calves were allowed to suckle their dam immediately after birth for about four days to receive colostrum. Weighting and ear tagging were also engaged within 24 hours after birth. After 4 days, calves were taken in to calf rearing pen and continued to feed recommended amount of whole milk for 98 days through artificial rearing system (bucket feeding) except the F1 calves, which have been suckling their dams until winning since 2002. Weaned calves were transferred to other pen and kept indoor until 6 months of age.

Milking has been practiced by hand until 2001. In 2002 milking machine has been installed and since then cows have been milking with milking machine twice daily (early morning and evening). The animal management was also supported with vaccination against major disease and treatment to control any incidence of diseases.

\section{Breeding program}

Pure Borena dams were mated with pure Friesian semen to produce the $50 \% \mathrm{~F}_{1}$ crosses while the $50 \% \mathrm{~F}_{1}$ is back crossed with pure Friesian semen to produce the $75 \%$ first generation. The later generations, $\mathrm{F}_{2}, \mathrm{~F}_{3}$ and $75 \%$ second generation were produced by inter se mating $50 \%$ male with $50 \%$ female and $75 \%$ male with $75 \%$ female. The Borena cattle used as a foundation stock for crossbreeding were brought from Borena pastoralists in the southern Ethiopia (there center of origin) and reared on station then inseminated randomly with semen from NAIC (national artificial insemination center) and WWS (worldwide sire) to produce required generations.

Seasonal breeding has been undertaken until 2000. Since then the mating practice was changed and has been undertaking throughout the year using AI (artificial insemination) with semen from locally recruited crossbred bulls or pure Friesian semen from NAIC and WWS. Sometimes natural service has been used when animals became repeat breeder with AI. In addition to herdsmen, teaser bull was reared with cows for heat detection. Cows detected in heat were mated using artificial insemination by qualified technicians. Cows not seen in heat after service for longer were diagnosed for pregnancy after 60 days of service.

\section{Data management}

Screenings of data were made to avoid manmade errors during data entrance on individual animal card or in the computer writing. The minimum truncation point for LL in this study was 100 days which regarded as incomplete lactation for analysis of LMY, DMY and LL. Lactation records of above eighth parities were pooled together in parity eight because of few records. The animals that have abnormal calving, (i.e., abortions and stillbirths) were not included in the analysis. 


\section{Method of data analysis}

The General Linear Model (GLM) procedure of Statistical Analysis System (SAS 2004) version 9.0 was employed to determine and compare the fixed effects of different genetic group, calving periods, calving seasons and parity for LMY, DMY and LL traits. Genetic group included in the analysis were broadly classified in to two based on the exotic blood levels $\left(50 \% \mathrm{~F}_{1}, \mathrm{~F}_{2}, \mathrm{~F}_{3}\right.$ and $75 \%$ first and second generations).

Different genetic groups were developed in different years depending on the objective of the research station (research direction) during the last 40 years. The years of calving ranged from 1978 to 2017 were grouped into 8 periods considering the similarity within year group. Thus each year group consisted 5 periods. For season of calving, months of the years were classified into 3 seasons based on rainfall distribution as dry season from October to February, short rain season from March to May and main rain season from June to September. The presences of any significant differences among fixed effects (genetic and non-genetic factors) were checked using least square mean separation of SAS procedure. The three productive traits (LMY, DMY and LL) were analyzed by the following model

$\mathrm{Y}_{\mathrm{ijkln}}=\mu+\mathrm{Y}_{\mathrm{i}}+\mathrm{S}_{\mathrm{j}}+\mathrm{G}_{\mathrm{k}}+\mathrm{P}_{\mathrm{l}}+\mathrm{e}_{\mathrm{ijkln}}$ Where;

$\mathrm{Y}_{\mathrm{ijkln}}=\mathrm{n}^{\text {th }}$ record of, $\mathrm{i}^{\text {th }}$ period, $\mathrm{j}^{\text {th }}$ season, $\mathrm{k}^{\text {th }}$ genetic group and $\mathrm{l}^{\text {th }}$ parity

$\mu=$ overall mean

$\mathrm{Y}_{\mathrm{i}}=$ effect of $\mathrm{i}^{\text {th }}$ period of Calving

$\mathrm{S}_{\mathrm{j}}=$ effect of $\mathrm{j}^{\text {th }}$ Season of Calving

$\mathrm{G}_{\mathrm{k}}=$ effect of $\mathrm{k}^{\text {th }}$ Genetic group $\left(50 \% \mathrm{~F}_{1}, \mathrm{~F}_{2}, \mathrm{~F}_{3}\right.$ and $75 \%$ first generation, second generation)

$\mathrm{P}_{1}=$ effect of $\mathrm{l}^{\text {th }}$ Parity of Dam $(1,2,3,4,5,6,7,8)$

$\mathrm{e}_{\mathrm{ijk} k \mathrm{n}}=$ random error associated with each observation

\section{RESULTS}

The overall mean with standard error of LMY of Borena x HF crosses in the present study was $2204.05 \pm 21.12$ $\mathrm{Kg}$. Results of the least square means and standard errors for fixed effects of genetic group, calving period, calving season and parity are summarized in Table 1 . LMY was significantly $(\mathrm{p}<0.001)$ affected by genetic group, calving period, calving season and parity.

Table 1 Least square means and standard errors of lactation milk yield.

\begin{tabular}{lll}
\hline Effects & Number of observations & \multicolumn{1}{c}{ LMY LSM \pm SE $(\mathrm{kg})$} \\
\hline overall & 2313 & $2204.05 \pm 21.12$ \\
Genetic group & 1598 & $2203.23^{\mathrm{b}} \pm 38.13$ \\
$50 \% \mathrm{~F}_{1}$ & 234 & $1697.09^{\mathrm{c}} \pm 71.82$ \\
$50 \% \mathrm{~F}_{2}$ & 139 & $1522.67^{\mathrm{c}} \pm 90.07$ \\
$50 \% \mathrm{~F}_{3}$ & 299 & $2957.46^{\mathrm{a}} \pm 72.98$ \\
$75 \%$ first generation & 43 & $2027.16^{\mathrm{b}} \pm 152.15$ \\
$75 \%$ second generation & & \\
Calving period & 23 & $1943.44^{\mathrm{bcd}} \pm 203.80$ \\
$1977-1982$ & 75 & $2105.72^{\mathrm{bc}} \pm 118.81$ \\
$1983-1987$ & 167 & $1670.22^{\mathrm{d}} \pm 79.92$ \\
$1988-1992$ & 183 & $2030.62^{\mathrm{c}} \pm 74.07$ \\
$1993-1997$ & 272 & $2373.78^{\mathrm{a}} \pm 72.94$ \\
$1998-2002$ & 370 & $2229.95^{\mathrm{ab}} \pm 67.88$ \\
$2003-2007$ & 565 & $2233.15^{\mathrm{ab}} \pm 60.69$ \\
$2008-2012$ & 659 & $2065.28^{\mathrm{c}} \pm 57.13$ \\
$2013-2017$ & & \\
Calving season & 1071 & $2162.46^{\mathrm{a}} \pm 54.70$ \\
Dry season & 626 & $2018.17^{\mathrm{b}} \pm 60.97$ \\
Short rain season & 616 & $2063.93^{\mathrm{b}} \pm 61.55$ \\
Main rain season & & \\
Parity & 690 & $1811.16^{\mathrm{d}} \pm 53.76$ \\
1 & 488 & $1983.23^{\mathrm{c}} \pm 60.86$ \\
2 & 347 & $2063.57^{\mathrm{bc}} \pm 66.98$ \\
3 & 245 & $2193.50^{\mathrm{ab}} \pm 75.37$ \\
4 & 187 & $2238.52^{\mathrm{a}} \pm 82.31$ \\
5 & 150 & $2136.28^{\mathrm{abc}} \pm 90.91$ \\
6 & 98 & $2111.67^{\mathrm{abc}} \pm 108.49$ \\
7 & 108 & $2114.25^{\mathrm{abc}} \pm 106.69$ \\
8 & & \\
\hline
\end{tabular}

Different superscripts $(\mathrm{a}, \mathrm{b}, \mathrm{c}, \mathrm{d})$ in the same fixed effect indicate differences among sample means, LMY = lactation milk yield 
Results of the least square means for fixed effects of genetic group, calving period, calving season and parity for DMY and LL are summarized in Table 2. The overall mean and standard error for DMY was $6.88 \pm$ $0.05 \mathrm{~kg}$ and for LL $326.69 \pm 2.03$ days. Both DMY and LL were significantly $(\mathrm{p}<0.001)$ affected by genetic group, calving period, calving season and parity.

Table 2 Least square means and standard errors of daily milk yield and lactation length.

\begin{tabular}{|c|c|c|c|}
\hline Effects & Number of observations & $\mathrm{DMY} \operatorname{LSM} \pm \mathrm{SE}(\mathrm{kg})$ & Lactation length $\mathrm{LSM} \pm \mathrm{SE}$ (days) \\
\hline Overall & 2186 & $6.88 \pm 0.05$ & $326.69 \pm 2.03$ \\
\hline \multicolumn{4}{|l|}{ Genetic group } \\
\hline $50 \% \mathrm{~F}_{1}$ & 1543 & $6.69^{b} \pm 0.083$ & $343.62^{b} \pm 3.56$ \\
\hline $50 \% \mathrm{~F}_{2}$ & 234 & $5.66^{c} \pm 0.16$ & $319.42^{c} \pm 6.68$ \\
\hline $50 \% \mathrm{~F}_{3}$ & 139 & $5.02^{\mathrm{d}} \pm 0.19$ & $319.25^{\mathrm{c}} \pm 8.37$ \\
\hline $75 \%$ first generation & 236 & $8.70^{\mathrm{a}} \pm 0.17$ & $374.05^{\mathrm{a}} \pm 7.24$ \\
\hline $75 \%$ second generation & 34 & $6.72^{b} \pm 0.37$ & $303.12^{c} \pm 15.73$ \\
\hline \multicolumn{4}{|l|}{ Calving period } \\
\hline 1977-1982 & 23 & $6.18^{\mathrm{cd}} \pm 0.44$ & $316.06^{\mathrm{cd}} \pm 18.98$ \\
\hline 1983-1987 & 75 & $5.88^{\mathrm{d}} \pm 0.26$ & $407.35^{\mathrm{a}} \pm 11.13$ \\
\hline 1988-1992 & 167 & $4.60^{\mathrm{e}} \pm 0.18$ & $374.99^{\mathrm{b}} \pm 7.50$ \\
\hline 1993-1997 & 183 & $5.55^{\mathrm{d}} \pm 0.16$ & $369.94^{b} \pm 6.94$ \\
\hline 1998-2002 & 272 & $7.58^{b} \pm 0.16$ & $314.78^{c} \pm 6.95$ \\
\hline 2003-2007 & 370 & $6.99^{c} \pm 0.15$ & $316.77^{\mathrm{c}} \pm 6.50$ \\
\hline 2008-2012 & 565 & $7.65^{b} \pm 0.14$ & $286.66^{\mathrm{d}} \pm 5.85$ \\
\hline 2013-2017 & 531 & $8.08^{a} \pm 0.14$ & $268.56^{\mathrm{e}} \pm 5.80$ \\
\hline Calving season & & & $\mathrm{ns}$ \\
\hline Dry season & 1027 & $6.67^{\mathrm{a}} \pm 0.12$ & $333.26 \pm 5.30$ \\
\hline Short rain & 585 & $6.40^{b} \pm 0.13$ & $329.03 \pm 5.90$ \\
\hline Main rain & 574 & $6.61^{\mathrm{a}} \pm 0.14$ & $333.39 \pm 5.96$ \\
\hline \multicolumn{4}{|l|}{ Parity } \\
\hline 1 & 653 & $5.24^{\mathrm{e}} \pm 0.12$ & $348.67^{\mathrm{a}} \pm 5.22$ \\
\hline 2 & 454 & $5.83^{d} \pm 0.14$ & $347.73^{a} \pm 5.92$ \\
\hline 3 & 318 & $6.52^{c} \pm 0.15$ & $330.45^{b} \pm 6.50$ \\
\hline 4 & 234 & $6.72^{b c} \pm 0.17$ & $341.44^{\mathrm{ab}} \pm 7.23$ \\
\hline 5 & 181 & $6.99^{\mathrm{ab}} \pm 0.18$ & $332.22^{b} \pm 7.85$ \\
\hline 6 & 147 & $6.79^{b c} \pm 0.20$ & $328.12^{\mathrm{b}} \pm 8.62$ \\
\hline 7 & 94 & $7.04^{\mathrm{ab}} \pm 0.24$ & $322.03^{b c} \pm 10.34$ \\
\hline 8 & 105 & $7.37^{\mathrm{a}} \pm 0.24$ & $304.46^{c} \pm 10.14$ \\
\hline
\end{tabular}

Different superscripts (a, b, c, d, e) in the same fixed effect indicate differences among sample means, DMY = lactation milk yield, ns; not significant.

\section{DISCUSSION}

\section{Lactation milk yield}

The overall mean result obtained in this study was slightly higher than the report of Gebrgziabher et al. (2014) who found $2111.91 \pm 16.88 \mathrm{~kg}$ for Borena $\mathrm{x}$ HF in central Ethiopia and Kumar et al. (2014) who reported $2123.43 \pm 65.67 \mathrm{~kg}$ for crossbred in Gondar, Ethiopia. Lower values were reported by various studies (Djoko et al. 2003; Ali et al. 2004; Haile et al. 2009; Kefena et al. 2011; Ashutosh et al. 2013) with $1703 \pm 12.1 \mathrm{~kg}$ for crossbred in Ghana, $1336.88 \pm 60.23 \mathrm{~kg}$ for Friesian $\mathrm{x}$ local in Bangladesh, $1798 \pm 25 \mathrm{~kg}$ for Borena $\mathrm{x}$ HF crosses, $2088.7 \pm 29.4 \mathrm{~kg}$ for Borena $\mathrm{x}$ HF crossbred in central highland of Ethiopia and $1506.75 \pm 71.37 \mathrm{~kg}$ for HF x local in Bangladesh, respectively. However, comparatively higher values of LMY were reported by Dash et al. (2015) $3976.77 \pm 41.03 \mathrm{~kg}$ for HF $\mathrm{x}$ Keran Fries in India and $3446 \pm 1112 \mathrm{SD}$ (standard deviation) by Kahi et al. (2000) for Sahiwal with temperate breed crosses. The difference of the present result from the authors reported elsewhere could be associated with animal management system followed by farms such as quality and quantity of feed ingredients provided, disease manifestation on each location, its control and prevention, type of breeds involved for crossbreeding and difference in level of exotic gene inheritance being studied in each location. Climate factors in which animals were managed might be also other source of variation among these studies.

The 75\% first generation was produced significantly $(\mathrm{p}<0.05)$ higher milk yield per lactation compared with other genetic groups and produced about $34.2 \%, 74.3 \%, 94.3 \%$ and $45.9 \%$ more milk than $50 \% \mathrm{~F}_{1}, \mathrm{~F}_{2}, \mathrm{~F}_{3}$ and $75 \%$ second generations, respectively in this study. This might be due to up grading the level of exotic inheritance from $50 \%$ to $75 \%$, which consequently increased the milk gene. It can also indicates that the level of management (feeding, health and other husbandry) provided by the farm was good to support the crossbred cows 
to express their genetic potential. The superiority of $75 \%$ genotype over $50 \%$ was also reported by some other studies conducted in the tropics (Million and Tadelle 2003; Haile et al., 2009). However, studies by Demeke et al. (2004), Kefena et al. (2006) and Gebregziabhere et al. (2013) could not detect significant difference between $50 \% \mathrm{~F}_{1}$ and $75 \%$ first generation. LMY was radically reduced by $506 \mathrm{~kg}(23 \%)$ from $50 \% \mathrm{~F}_{1}$ to $\mathrm{F}_{2}$ and $930 \mathrm{~kg}$ (31 \%) from $75 \%$ first generation to $75 \%$ second generation. This might be because of the significant recombination losses (lack selection of elite sires for inter se mating and segregation effect, which causes decrease in heterosis on inter se mated generation). Demeke et al. (2004) on his study indicated that $526 \pm 192$ $\mathrm{kg}$ of LMY was lost due to recombination effect when Borena was crossed with HF.

The highest average LMY $(2373.78 \mathrm{~kg})$ was observed during 1998-2003 while the lowest LMY $(1670.22 \mathrm{~kg})$ was recorded during the period 1988-1992. The three-period of calving (1998-2002, 2003-2007 and 2008-2012) were the most favorable periods for animals to perform better LMY. The variation in LMY from one period of calving to other could be attributed to changes in herd size, change of the climate, and inconsistent management practices across period of calving. The source of fund for animal management (for feed, veterinary inputs purchase and other husbandry cost) was based on the yearly budget allocated by the state government and the amount varies across the years. As a result, the performance of the cows varies among the periods of calving as the level of management fluctuates over the year depending on availability of the fund. The inconsistent of period of calving trend over LMY was in agreement with (Million and Tadelle 2003; Demeke et al. 2004).

We found that LMY was sensitive to seasonal variation. Higher average LMY was exhibited in dry season but the other two seasons were no significant effects. Seasonal variation on animal performance was expected to be primarily a manifestation of variation in feed quality and quantity. According to the farm management practices of this herd, the cows were not allowed for grazing during rainy season as the pastureland was protected for hay production. In addition, sometimes there were shortages of feed during main rainy season due to delays of annual budget release to purchase feeds and veterinary inputs. Thus, cows that calved during the dry season might enjoyed better management as they were allowed for grazing on pastureland and supplemental feed and veterinary inputs were more available than other two seasons in the farm.

The analysis of variance revealed that LMY significantly $(\mathrm{p}<0.001)$ differed among parities. Similar finding in Borena x HF crosses were reported by (Kefena et al. 2006; Haile et al. 2009; Gebregziabhere et al. 2013; Gebregziabher et al. 2014). Maximum LMY was observed in parity five and minimum yield was recorded in parity one. LMY was increased from parity one to five by $23 \%$ and constant then after. The gradual increased in milk yield from first to five parities might be attributed to the growth with respect to body size and increase in the active of secretory tissues of udder due to recurring pregnancies. Unlike the present study, Belay et al. (2012) reported decreasing trend of LMY when parity increases.

\section{Lactation length}

The mean LL estimated by this study (326.69 \pm 2.03 days) is almost similar with finding of Kahi et al. (2000), Kumar et al. (2014) and Dash et al. (2015) with the values of $326 \pm 72$ (SD) days for Sahiwal with temperate breed crosses, $325.12 \pm 61.28$ days for crossbred in Ethiopia and $326.57 \pm 2.60$ days for HF x Keran Fries in India, respectively. Suhban et al. (2000), Ali et al. (2004) and Kefena et al. (2006) reported slightly higher estimation from the present result with values of $503.0 \pm 6.36$ days for Pakistani crossbred, $338.19 \pm 9.98$ days for Bangladesh crossbred and 360.76 \pm 6.11 days for Ethiopian crossbred dairy cattle, respectively. However, lower estimation of $204 \pm 27.8$ and $234.0 \pm 24.0$ days were reported by Djoko et al. (2003) and Ashit et al. (2013), respectively. The differences in LL might be attributed to variance in farm management system that some dairy farms have their own criteria to dry their cows. In addition, the types of breeds involved for crossbreeding and level of exotic gene inheritance could make difference on length of lactation period.

Lactation length was significantly $(\mathrm{p}<0.001)$ varied among genetic groups. The $75 \%$ first generation was longest ( $374.05 \pm 7.24$ days) lactation length followed by $50 \% \mathrm{~F}_{1}$ crosses ( $343.62 \pm 3.56$ days). Lactation length increased as proportion of Friesian gene increased in this study. This could be associated with longer calving interval and higher milk yield potential of $75 \%$ Friesian inheritance. The shortest lactation length was recorded with $75 \%$ second generation. However, no significant $(\mathrm{P}>0.05)$ differences were observed among $50 \% \mathrm{~F}_{2}, \mathrm{~F}_{3}$ and $75 \%$ second generations. LL was declined from $F_{1}$ to $F_{2}$ and $F_{3}$ crosses although the proportions of exotic genes are similar to that of $F_{1}$ crosses.

Trend analysis of LL based on calving period showed that there is a decreasing pattern across 1983-1987 to 2013-2017, which might be a management decision in which cows are milked 305 days to bring standard lactation length since 2003, which means involuntary drying off cows. Highest and lowest LL recorded in 19831987 and 2013-2017, respectively. However, no significant $(\mathrm{P}>0.05)$ values were observed among calving period of 1998-2002, 2003-2007 and 2013-2017.

Lactation length was not significantly affected $(p>0.05)$ by season of calving. This result is in line with the finding of (Demeke et al. 2004; Haile et al. 2009; Kefena et al. 2006). On the other hand least square mean showed that significant $(\mathrm{p}<0.05)$ differences were observed among parities on LL. The longest LL was observed in first parity and the shortest LL was observed on $8^{\text {th }}$ parity. Cows at first parity was prolonged open period due 
to lactation stress mainly during the first lactation trimester and thus the farm management could allow the cows for more days on lactation to be economical. Similar with present study, decreasing trend of LL was observed from parity one to eight (Lateef, 2007; Haile et al. 2009).

\section{Daily milk yield}

Daily milk yield obtained from $75 \%$ first generation $(8.70$ liter $)$ was significantly $(\mathrm{P}<0.05)$ higher compared to other genetic groups. The present result is comparable with the report of (Haile et al. 2009). However, the significant difference observed in this study is contradicted with studies by Demeke et al. (2004) and Gebregziabher et al. (2013) who reported that upgrading from 50\% to higher Friesian fractions for HF $\mathrm{x}$ indigenous crosses had shown no significant differences for milk yields. The difference of the present study from others literature could be due to management difference and number of observation studied. The $75 \%$ first generation was produced 23.1 and $22.8 \%$ more DMY than $50 \% \mathrm{~F}_{1}$ and $75 \%$ second generations, respectively. However, no significant ( $\mathrm{P}>0.05)$ difference was observed between $50 \% \mathrm{~F}_{1}$ and $75 \%$ second generations in this study. DMY was decreased from $50 \% \mathrm{~F}_{1}$ to $\mathrm{F}_{2}$ and $\mathrm{F}_{3}$ and from $75 \%$ first generation to second-generation crosses. This might be reduction of heterosis and increase of recombination loss during gamete recombination at time of crossing between the two breeds. In support of this, Demeke et al. (2004) on his study indicated that 3.0 $\pm 0.4 \mathrm{~kg}$ of DMY was lost due to recombination effect when Borena was crossed with HF breed.

Period and season of calving had significant $(\mathrm{P}<0.05)$ effect on daily milk yield. Higher and lower DMY was recorded during the period 2013-2017 and 1988-1992, respectively. Cows calved during dry and main rain season were produced better DMY than short rain season. Variation in availability of supplemental feed and access to pasture during the calving period, season and variability of weather across years and season could be the determinate factors, which affects daily milk of study population. This result is contradicted with Haile et al. (2009) who found seasonal variation had not significant $(\mathrm{p}>0.05)$ effect on DMY.

Significantly $(\mathrm{P}<0.05)$ higher DMY was observed in parity eight and lower yield was observed at parity one. Even though, no clear significant difference was observed from forth to eighth parity, DMY was increased as parity increase in this study. The present result indicated that cows are produced more milk as they became matured enough (associated with growth in body size and secretory tissues of udder and adaptation to lactation stress).

\section{CONCLUSION}

This study showed that the productive traits were influenced by different environmental factors. The traits measured showed significant variation among genetic groups, calving period, calving seasons and parities and which indicating that a remarkable improvement can be achieved through better management decision and rigorous selection. Milk production in the first generation crosses increased more compared to second and third generations. Back crossing the $F_{1}$ to the European breeds were brought an increase milk yield in this study. The results of grades higher than $50 \% \mathrm{~F}_{1}$ exotic gene $(75 \%)$ in the present study revealed that performance in productive traits (LMY, LL and DMY) continued to increase with increasing proportion of Friesian gene. Intense selection on both parental lines for each genotype should be implemented to improve overall milk production and associated traits.

\section{ACKNOWLEDGEMENT}

The authors would like to thank Ethiopian Institute of Agricultural Research, Holetta Agricultural Research Center for allowed us to exploit long term crossbreeding data.

\section{REFERENCE}

Ali Reza Ahmed, Sarder Safiqu Islam, Nargis Khanam, Ayesha Ashraf. (2004). Genetic and phenotypic parameters of milk production traits of crossbred cattle in a selected farm of Bangladesh. Journal of Biological Sciences, 4 (4): 452-455.

Ashit Kumar Paul, Abdullah-Al-Maruf, Pankaj Kumar Jha, Golam Shahi Alam, M. (2013). Reproductive performance of crossbred and indigenous (Desi) dairy cows under rural context at Sirajgonj district of Bangladesh. Journal of Embryo Transfer, 28(4): 319-324.

Ashutosh Das, Gous Miah, Mukta Das Gupta, Md Kabiru Islam Khan. (2013). Genetic parameters of Holstein crossbred on commercial dairy farms in Chittagong, Bangladesh. Indian Journal of Animal Research, 47 (4): 327-330

Belay Duguma, Yisehak Kechero, Janssens, G.P.J. (2012). Productive and reproductive performance of zebu x Holstein-Friesian crossbred dairy Cows in Jimma Town, Oromia, Ethiopia. Global Veterinarian, 8 (1): 6772.

Braännäng Eskil and Person Sven. (1990). Ethiopian animal husbandry handbook. Southeastern agricultural zone, Uppsala, Sweden.

CSA (Central Statistical Authority). (2017). Agricultural sample survey 2017/2018, Volume II Report on 
livestock and livestock characteristics (private peasant holdings). Addis Ababa, Ethiopia.

Cunningham, E.P., Syrstand, O. (1987). Crossbreeding Bos indicus and Bos taurus for milk production in tropics. FAO (Food and Agricultural Organization of the United Nation) Animal Production and Health paper No. 68 , Rome, Italy.

Dash, S.K., Gupta, A.K., Avtar Singh, Manoj, M., Pushp Raj Shivahre, Panmei, A., Sahoo, S.K. (2015). Covariance component and genetic parameter estimate of production and fertility traits in Holstein Friesian cross cattle using repeatability animal model. Indian Journal of Animal Sciences, 85 (10): 1092-1097.

Demeke Sindros, Neser F.W.C., Schoeman, S.J. (2004). Estimates of genetic parameters for Borena, Friesian and crosses of Friesian and Jersey with the Borena cattle in the tropical highlands of Ethiopia: milk production traits and cow weight. Journal of Animal Breeding and Genetics, 121: 163 - 175.

Djoko, T.D., Mbah, D.A., Mbanya, J.N., Kamga, P., Awah, N.R., Bopelet, M. (2003). Crossbreeding Cattle for Milk Production in the Tropics: Effects of genetic and environmental factors on the performance of improved genotypes on the Cameroon western high plateau. Revue Élev. Méd. vét. Pays trop. 56 (1-2): 6372.

FAO (Food and Agricultural Organization of the United Nation). (2010). Breeding strategies for sustainable management of animal genetic resources. FAO Animal Production and Health Guidelines No. 3, Rome, Italy.

Gebregziabher Gebreyohannes, Skorn Koonawootrittriron, Mauricio Aguirre Elzo, Thanathip Suwanasopee. (2013). Variance components and genetic parameters for milk production and lactation pattern in an Ethiopian multi-bred dairy cattle population. Asian Australas journal of Animal Science, 26 (9): 1237 1246.

Gebregziabher Gebreyohannes, Skorn Koonawootrittriron, Mauricio Aguirre Elzo, Thanathip Suwanasopee. (2014). Genotype by environment interaction effect on lactation pattern and milk production traits in an Ethiopian dairy cattle population. Kasetsart Journal of Natural Science, 48: 38 - 51.

Griffin, M. (1999). Outlook for the dairy sector to the year 2005. Paper presented at the international symposium on international prospect for dairying in the next WTO (World Trade Organization) Negotiating Round, 3-4 June 1999. Buenos Aires, Argentina.

Haile Aynalem, Joshi, B.K., Workneh Ayalew, Azage Tegegne, Singh, A. (2009). Genetic evaluation of Ethiopian Borena cattle and their crosses with Holstein Friesian in central Ethiopia: milk production traits. Animal, 3(4): 486 - 493.

Kahi, A.K., Thorpec, W., Nitterd, G., Baker, R.L. (2000). Crossbreeding for dairy production in the lowland tropics of Kenya I. Estimation of individual crossbreeding effects on milk production and reproductive traits and on cow live weight. Livestock Production Science, 63: 39 - 54.

Kefena Effa, Hegde, B.P., Tesfaye Kumsa. (2006). Lifetime production and reproduction performances of Bos taurus $\mathrm{x}$ Bos indicus crossbred cows in the central highlands of Ethiopia. Ethiopian Journal of Animal Production, 6 (2): 1-16.

Kefena Effa, Zewdie Wondatir, Tadelle Dessie, Aynalem Haile. (2011). Genetic and environmental trends in the long-term dairy cattle genetic improvement programs in the central tropical highlands of Ethiopia. Journal of Cell and Animal Biology, 5(6): 96 - 104.

Kumar Niraj, Alemayehu Eshetie, Abreha Tesfaye, Hailelulealem Yizengaw. (2014). Productive performance of indigenous and Holstein Friesian crossbred dairy cows in Gondar, Ethiopia. Veterinary World, 7(3): 177181.

Lateef Muhammed. (2007). 'Production performance of Holestien Friesian and Jersey cattle under sub-tropical environment of the Punjab, Pakistan'. PhD Thesis. Department of livestock management University of Agriculture, Faisalabad, Pakistan.

McDowell, R.E. (1985). Crossbreeding in tropical areas with emphasis on milk, health and fitness, Journal of Dairy Science, 68: 2418 - 2435.

Million Tadesse and Tadelle Dessie. (2003). Milk production performance of Zebu, Friesian and their crosses in Ethiopia. Livestock Research for Rural Development (15)3.

MOARD (Ministry of Agriculture and Rural development). (2007). Livestock Development Master.

Suhban Qureshi, M., Asm tullah Khan, Khud, Bakhsh Mirbahar, Uris Samo, M. (2000). Productive and reproductive performance and their interaction in crossbred cattle under field conditions in district Bannu. Pakistan Veterinary Journal, 20 (1).

Tesfaye, A. (1990). Livestock development in the peasant sector of highland of Ethiopia: Some policy issues and implications. In: African Livestock Policy Analysis Network (ALPAN), Network paper No 24, June 1990. ILCA (International Livestock Center for Africa), Addis Ababa, Ethiopia.

Yohannes Gojam, Million Tadesse, Kefena Effa, Direba Hunde. (2016). Performance of crossbred dairy cows suitable for smallholder production systems at Holetta Agricultural Research Centre. Ethiopian Journal of Agricultural Science, 27(1): 121-131. 